\title{
The changing landscape of ePortfolios: A case study in one Australian university
}

\author{
Urszula Coffey \\ Griffith University
}

Kevin Ashford-Rowe

Australian Catholic University

The potential of ePortfolios for both students and staff has generated considerable interest and investment by universities over the past ten years or so within Australia. Despite funded projects, ePortfolio specific conferences and a range of commercial and open software, there is not wide spread uptake of ePortfolios, although many universities continue to try and test a range of different options. This paper reports upon the experience of an Australian university when considering implementation and uptake of ePortfolio technology between 2008 and 2011. It describes the technological and sectoral factors that have to some extent shaped Australian ePortfolio context and affected the institutional ePortfolio initiative at Griffith University.

\section{Introduction}

\section{ePortfolio technology}

ePortfolio technology derives from the long tradition of paper portfolios often used within higher education for showcasing skills and achievements. As information technology has become more sophisticated portfolios have begun to shift in format from paper to electronic. The Internet and the emergence of Web 2.0 technologies have further facilitated the ease with which information can be published and accessed. It is not surprising that it was with the emergence of these Web 2.0 technologies that the first ePortfolio tools began to emerge, seeking to integrate the increasingly interactive Web 2.0 technologies into the educational context.

ePortfolio technology provides learners with the personal learning space where they can collect, structure and present their learning content created as a result of learning activities. In the academic context, ePortfolio activities often require students to demonstrate a range of competencies or professional skills, reflect on learning experiences, demonstrate development or showcase achievements. This is referred to broadly as ePortfolio practice. In higher education, ePortfolio practice is widely used to facilitate personal and professional development in variety of settings, including situated learning, work integrated learning, professional accreditation and recruitment.

The wide range of ePortfolio tools available includes commercial products, in-house developed systems, open source software, and common access technologies in the cloud. Their different functionalities offer institutions a range of specific affordances. Commercial off-the-shelf products, for example PebblePad, Desire2Learn, eWebfolio or Career Board, are relatively quick to implement, but tend to provide onesize-fits-all functionality and not support customization at an institutional level. The in-house developed systems often offer high levels of customisation as they are purpose-built to the specific requirements of the institution, but can be challenging to coordinate across the institution and may have high initial development and infrastructure cost. Open source software initiatives, such as Open Source Portfolio (OSP) or Mahara, are informed and managed by a community of users. These may significantly lower the development costs, but make the development vulnerable to the community dynamics, and the implementing organisation is still required to either provide technical infrastructure or use an external hosting service. Finally, open access tools in the cloud, such as Google and WordPress, are flexible, userfriendly technologies, however they are not education-specific, thus their academic integration may be quite challenging. 


\section{ePortfolio context in the Australian higher education sector}

In July 2008 the Australian Information and Communication Technology in Education Committee (AICTEC) presented two documents, which have had a direct impact on the implementation of ePortfolio technologies in the Australian higher education sector. Firstly, the Joint Ministerial Statement on Information and Communication Technologies in Australian Education and Training: 2008-2011 provided ministerial support for the enhancement of educators' ICT capabilities by fostering national collaboration on joint educational solutions, exchange of knowledge within and between institutions, and standardisation of education and training environments (AICTEC, 2008a). The document also promoted lifelong learning, person-centred flexible learning and encouraged the engagement of learners 'with state of the art tools which enabled new forms of learning, collaboration, innovation and communication' (AICTEC, 2008a, p. 1). Secondly, The Charter of Principles for Cross-Sectoral Collaboration on Interoperability across the Australian Education and Training Sectors supplemented the Ministerial Statement, by encouraging the development of interoperability standards tailored to the Australian education system and providing guidelines for collaborative initiatives (AICTEC, 2008b).

While the above mentioned documents set the climate for collaboration in Australian higher education, the Government supported the tertiary ePortfolio initiative more directly through the Australian Learning and Teaching Council (ALTC) by funding the Australian ePortfolio Project (AeP). The AeP was led by ePortfolio experts from Queensland University of Technology (QUT). QUT and the University of Wollongong (UoW) were both early adopters of ePortfolios in Australia. QUT released an in-house developed student ePortfolio in 2004 to assist their graduating students in the transition from university to employment. UoW implemented their customised Blackboard ePortfolio for Vista as an enterprise ePortfolio solution in 2007 and developed two discipline-specific ePortfolio tools for Education and Medicine Faculties. The ePortfolio experience and expertise of these early adopters played a key role in the ePortfolio discussion in Australia's tertiary education.

The AeP emphasized the need for strong academic integration of ePortfolio tools with learning and teaching outcomes of various disciplines and learning contexts, and providing staff with support and guidance to promote good practice (Hallam et al., 2008). From the very beginning, the emphasis was put not on technological development, but curricular integrity and the development of an ePortfolio culture (Hallam et al., 2008). The AeP produced three reports, in 2008, 2009 and 2010, that guided the Australian universities' approach to ePortfolio technology adoption and use, and they led to establishing the annual Australian ePortfolio Symposium in 2008 , as a chief forum for networking and promoting ePortfolio good practice in Australian higher education.

The AeP Supplementary Report released in 2010 noted that the communities of practice and the crosssectoral exchange of knowledge have benefited the whole sector by deepening the understanding of ePortfolio practice and increasing the number of successful ePortfolio initiatives (Hallam et al., 2010). This report also observed that more first-hand experiences with the ePortfolio tools noticeably improved the ePortfolio policies in place, and although the coordination of ePortfolio practice on a program level was still rare and ePortfolio activities in courses considered 'patchy', there was 'less of a sense of isolation, with collaborative activity bringing together different players in the institution' (Hallam et al., 2010, p. 35). Appropriate funding and staffing, along with academic scaffolding, IT support for students, good planning and appropriate staff development were emphasized as the critical success factors in the ePortfolio initiatives.

The AeP findings were informed by in-depth research into ePortfolio adoption in higher education in Australia and around the world. They presented great value to Australian universities still considering their approach to ePortfolios and were particularly informative in the consideration of such implementation at Griffith University.

\section{ePortfolio experience at Griffith University}

\section{Griffith ePortfolio Project}

In the wake of the first Australian National ePortfolio Symposium that took place in early 2008 in Brisbane, Griffith University initiated an ePortfolio Project. At the time, the university was conducting a 
major review of its learning and teaching agenda and as the expectations surrounding ePortfolios in higher education were still highly inflated (Gartner, 2008) it was of the university's interest to investigate and consider how ePortfolio technology can support university learning and teaching. The project was funded through an internal grant for learning and teaching and sponsored by learning and teaching support services.

The ePortfolio Project set out to gauge the level of interest in using ePortfolio technology across the university and to specify user requirements to guide the evaluation of the available ePortfolio tools. The project's activities were guided by a small interdisciplinary team, which included representatives from academic staff, learning and teaching support, IT infrastructure experts, Griffith Institute of Higher Education and Careers \& Employment Services.

\section{Method}

An institutional learning management system data analysis was conducted to identify potential ePortfolio practitioners. However, in the process of the initial enquiries it soon became apparent that knowledge of ePortfolio technology and its academic application was neither consistent nor universal at the university. It was agreed that a series of presentations delivered directly to academic colleagues within their existing schools would be one mechanism by which the project might seek to improve understanding of ePortfolio technology, and gauge academics' interest and needs surrounding ePortfolio practice. A total of 19 presentations were delivered across the university, with a particular interest observed within the disciplines of both health and education. As a result of the extensive information campaign that followed, a total of 60 staff members representing 24 out of the 30 Griffith schools from across the university expressed an initial interest in supporting the project. Of those, 45 academics from 22 schools representing a range of disciplines from health, arts, education, law, business and engineering provided feedback via a completed ePortfolio questionnaire (if you are interested in a copy please contact the first author). This supplied primary data for the statistical analysis that fed into the project's findings. The questionnaire was designed to capture and compare the existing and potential portfolio practitioners and their needs, to measure the level of interest in enhancing ePortfolio practice in learning and teaching and allow for a meaningful evaluation of the existing ePortfolio technologies. The additional feedback received from some academic ePortfolio practitioners received in a narrative format via email, phone, written case study or interview was utilized as extended commentary to support data interpretation. Other university areas, such as careers, work integrated learning and research also provided information regarding their needs in an interview format. The university wide enquiry allowed the project to identify the groups of institutional ePortfolio stakeholders and their specific needs to better understand the ePortfolio functionality in demand.

The qualitative analysis of the primary and secondary data allowed capturing some of the existing ePortfolio practice at Griffith, measuring the level of interest in using ePortfolio tools and establishing the ePortfolio functionality in demand. The identified user requirements informed the development of The Griffith ePortfolio Matrix (see Appendix A), a framework deployed to guide the evaluation of ePortfolio technologies. It also assisted in examining the existing Griffith technological environment against the required ePortfolio capabilities.

\section{Results}

In 2008, the 45 academic participants confirmed a strong interest in ePortfolio tools, particularly in the health $(n=12)$, education $(n=11)$ and arts $(n=11)$ disciplines, with significantly lesser interest in science $(n=6)$ and business $(n=5)$. Just over half of the respondents $(n=24)$ reported using electronic portfolios in their current teaching practice; of this number one third came from the School of Education $(n=8)$. The main objectives of the reported ePortfolio practice were reflection $(38 \%, n=17)$, recording practical experience $(33 \%, \mathrm{n}=15)$ and showcasing achievement $(29 \%, \mathrm{n}=13)$. ePortfolios for recording graduate attributes $(20 \%, n=9)$, managing learning progress $(18 \%, n=8)$ and other selected purposes were used to a lesser extent. It was reported that electronic and paper portfolios were used in a similar capacity, nearly always in student assessment, with $42 \%$ of current practitioners $(n=10)$ still utilising paper alone. For the remaining 58\% $(\mathrm{n}=14)$ who used electronic portfolios in their teaching, the tools of choice included websites $(n=7)$, emailed Word documents $(n=5)$, and Web 2.0 tools $(n=6)$, including wikis and blogs 
integrated within the university's technological infrastructure, as well as external tools, for example Google Sites.

Below is a brief overview of the identified technologies and resources relevant to ePortfolio practice and available to the Griffith academic community in 2008 :

- Expo Lx:

A basic wiki and blog creator integrated within the university's learning management system. It was user-centred, but lacked a structured data repository that would allow users to reuse their content, and it suffered from a number of issues that affected its usability. In 2008 it was being used in education and midwifery courses for professional development and work integrated learning ePortfolios.

- Dreamweaver:

A website building software available to students on the university computers. It required from students, web authoring skills and the provision of data storage solutions.

Used with Information and Communication Technology (ICT) Education students for professional development ePortfolios, this solution was considered ineffective and replaced by Google Sites.

- Google Sites:

An open access online tool for creating simple websites, available in the Google cloud, in 2008 still unsupported by the university.

In 2008 it was successfully adopted by the ICT Education program for student professional development ePortfolios.

- Graduate Attributes Toolkits:

A collection of resources for course convenors focused on embedding graduate attributes in course activities to support the renewed Griffith Graduate Statement. It was identified as a potential guide for academic integration of ePortfolio practice for recording graduate attributes on a program level. In 2008 it was still under development.

- Standout Resume Creator:

This basic tool available to all Griffith students provided resources that could effectively support career ePortfolios.

- Career Board

This university careers system offered a basic ePortfolio tool for career ePortfolios. In 2008 the ePortfolio component was being considered but was not yet available to Griffith users.

At that time, in order to measure the extent to which the available technological environment at Griffith fulfilled academic needs in their ePortfolio practice, and to identify the ePortfolio functionality in demand, the ePortfolio questionnaire set out to capture both existing and intended ePortfolio practice, should an ePortfolio tool be implemented (Figure 1).

As illustrated by Figure 1, the comparison of data revealed an apparent gap between the existing and intended ePortfolio practice at Griffith. This discrepancy was indicative of a potential demand for ePortfolio functionality unavailable within the existing technological environment. It also suggested strong interest in increasing the ePortfolio practice, as indicated by the study participants.

Showcasing achievements, Reflection and Recording practical experience were the most common academic deployments of ePortfolio in both, existing and intended practice. The biggest potential increase in ePortfolio practice was noted in Showcasing achievements (from 29\% to 78\%) and Managing learning progress (from $18 \%$ to $60 \%$ ), thus indicating high interest from academic respondents in further enhancing these practices. A total of $56 \%$ of the respondents indicated an intention to use ePortfolios with students for Attaining graduate attributes, which in contrast with the existing $20 \%$ of the declared practitioners, indicated a significant potential growth of the practice believed to be highly beneficial to student employability. While the reported practice of Evidencing acquisition of graduate attributes at the program level was marginal at the time, the respondents commonly acknowledged that a template-driven, user-centred ePortfolio tool supported by a discipline-specific framework would be very suitable for the evidence-driven skill mapping. Nearly half of the 45 surveyed academics $(n=21)$ saw merit in utilising an ePortfolio tool to support students' professional accreditation; greater than four times the reported existing practice $(\mathrm{n}=5)$. 


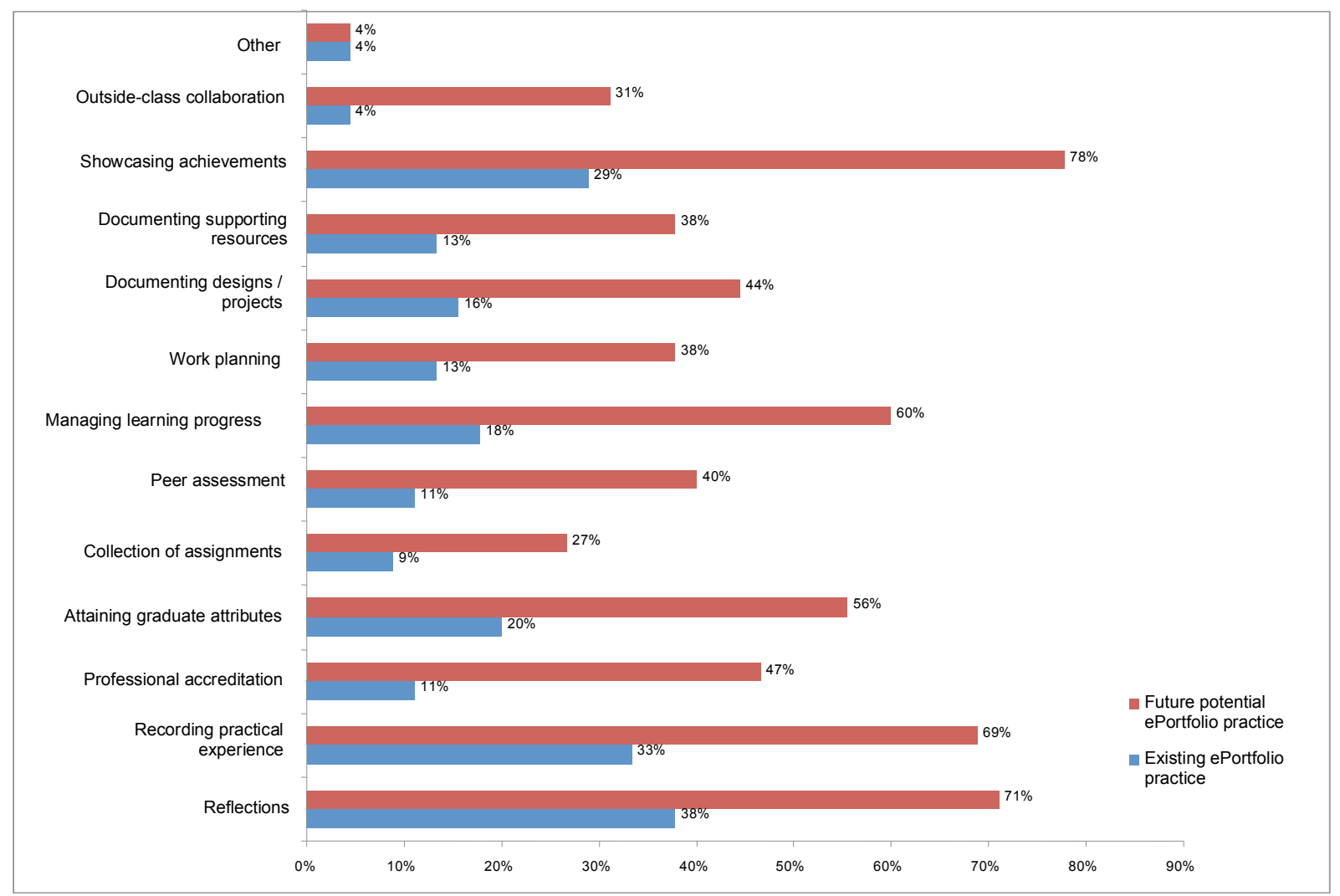

Figure 1. The gap between the existing and future potential ePortfolio practice at Griffith University in 2008

It was noted that $75 \%$ of the respondents considered to engage students with ePortfolios for at least the length of program or possibly also for life. This finding meant that in order to support a broader engagement of academics and students alike, the ePortfolio technology of choice would need to support portability of the learners' content, or the university would need to enable students with a lifelong access to the tool. While a desirable feature, lifelong access had institutional implications on the data storage, intellectual property, copyright liability and assurance of appropriateness of learners' content and therefore, would require careful consideration in the ePortfolio policy.

The survey results pointed towards a potential increase in the number of ePortfolio activities that could occur in learning and teaching, if a suitable tool were made available. The ePortfolio tool of choice, as identified by survey participants, had a number of key requirements: it was to be a user-friendly, template-driven tool integrated within the university's technological environment, that would support the storage of documents, images and video files. Lifelong access to the tool or content portability were considered essential for engagement of academics and students.

The top challenges of ePortfolio implementation from the academic perspective were identified as $70 \%$ of the respondents expressed concern about availability of sufficient support when adapting the ePortfolio tool to the individual needs of their discipline, program or course, and 57\% expressing further concern about staff computer literacy. Many academic teachers did not feel sufficiently confident in their IT skills, stressing the need for support when engaging in any blended learning initiative. Staff adaptability was also noted as a factor.

The ePortfolio questionnaire allowed the project team to capture ePortfolio practice of interest and identify the functionality in demand. This information was then used to guide the evaluation of ePortfolio technology against the identified requirements. The comparative evaluation of 11 ePortfolio tools conducted and documented using the ePortfolio Matrix, concluded that there was still a relative degree of 
immaturity in ePortfolio technologies and no one tool was identified as a sufficient solution for an enterprise ePortfolio system that could effectively support the ePortfolio practice at Griffith. The project findings were presented to the executive group and the project participants, and after careful consideration the enterprise ePortfolio initiative was temporarily suspended.

\section{1 review of ePortfolios}

The increasing demand from within the health disciplines to trial the ePortfolio technology in support of work integrated learning brought the ePortfolio tools back onto the agenda at Griffith University. The review of the 2008 ePortfolio Project findings conducted between October 2011 and March 2012 by the learning and teaching support services established a changed institutional and sectoral context with some crucial developments pertinent to the university's ePortfolio capability. An updated literature review revealed a significant increase in the number of ePortfolio publications internationally in comparison to 2008, with emergence of publications such as the International Journal of ePortfolio (IJeP), gathering ePortfolio-specific articles describing academic integrations of ePortfolio practice at all levels: institution (Peet et al., 2011), program (Lowenthal, White \& Cooley, 2011; Jarrott \& Eubanks Gambrel, 2011; Shada, Kelly, Cox \& Malik, 2011) and course (Ramirez, 2011; Turns, Sattler, Eliot, Kilgore \& Mobrand, 2012). Many of the case studies provided a proof of concept for technology-enhanced ePortfolio learning. They also offered a wealth of practical information uncovering the common issues and success factors in ePortfolio initiatives in various academic contexts, and evaluated effectiveness of various solutions, thus establishing a knowledge base that could effectively guide new ePortfolio adopters through their own experience.

Within Griffith University's learning and teaching environment, the following changes were noted:

- Google tools:

Throughout 2010 and 2011, the University adopted Google as the enterprise communication and collaboration solution for students and staff. The new set of enterprise tools (Gmail, Google Sites, Google Documents, etc.) provided an integrated ePortfolio capability available to all institutional users as of the end of 2011.

- Graduate Attributes Toolkits:

The new Graduate Statement and Graduate Attributes Toolkits completed in 2009 provided an academic framework with guidelines for evidencing graduate attributes across various disciplines. This strategic work informed a university-wide curriculum renewal, which could be further supported by ePortfolio practice of attaining graduate attributes on course or program level.

- Career Board:

In late 2012, the Resume Builder and ePortfolio tool integrated within the university's career system were enabled to support student career development.

The newly gained ePortfolio capability integrated within the university's technological environment provided the Griffith academic community with new opportunities to gain first hand experience with ePortfolios and explore ways in which to effectively integrate them with the academic curriculum and the institutional requirements for recordkeeping and assessment. Some of the issues that have hampered the ePortfolio tools uptake in previous years, for instance content mobility between the tools or data storage allowance when enabling student lifelong access, had become obsolete with Google as an enterprise-wide solution; Google cloud provided all Griffith students free, lifelong accounts with high data storage allowance, thus offering technological capacity that encouraged student engagement and supported student-centred, lifelong learning. In addition, the Career Board ePortfolio tool provided an alternative for career ePortfolios. Career and Employment Services planned to develop supporting resources to guide the tool's use and provide student lifelong access to support graduate employability and alumni connections.

Outside of the University's technological ecosystem, the 2011 review revealed further ePortfolio developments. Technical developments included the Leap $2 A$ open specification for ePortfolio portability and interoperability between the ePortfolio systems. Leap2A has been successfully implemented in number of ePortfolio solutions, including PebblePad and Mahara, the two most commonly adopted ePortfolio technologies in the Australian tertiary sector in 2011 (see Table 1). It enabled learners to transfer information from one ePortfolio system to another as they move between colleges and 
universities, thus reducing a risk of data being locked into one system (JISC, 2010), and offering a significant enhancement to the agenda of continuous learning in Australia.

Table 1

Uptake of the ePortfolio (eP) tools in 21 Australian universities (2008-2011)*

\begin{tabular}{ccc}
\hline IRU** & eP in 2008 & eP in 2011 \\
Griffith & - & Google \\
James Cook & - & Career Board ePortfolio \\
Newcastle & - & (PebblePad trial 2012) \\
La Trobe & PebblePad trial & - \\
Murdoch & - & PebblePad \\
Flinders & PebblePad trial & PebblePad \\
Charles Darwin & Blackboard eP trial & PebblePad aka FlindersPLus
\end{tabular}

\begin{tabular}{ccc} 
Other Universities & Student ePortfolio & \\
\hline QUT & Mahara & Student ePortfolio \\
Southern Queensland & Blackboard eP for Vista \\
Wollongong & (later discontinued) & Mahara \\
Charles Sturt & - & (Mahara trial 2012) \\
Central Queensland & - & PebblePad \\
Ballarat & - & Mahara \\
Tasmania & - & Mahara \\
Curtin & - & PebblePad \\
RMIT & - & iPortfolio \\
South Australia & - & PebblePad \\
Sydney & - & PebblePad \\
Victoria & - & PebblePad \\
Adelaide & & PebblePad \\
Macquarie & - & Mahara trial 2010 \\
\end{tabular}

\footnotetext{
* Data comes from the environmental scan conducted by the authors in November 2011.

** IRU - Innovative Research Universities is a network of seven Australian universities that conduct research of national and international reach (http://iru.edu.au/).
}

Another noticeable development was the commercial service of outsourcing the ePortfolio data storage for open source ePortfolio solutions, such as Mahara. This allowed universities to considerably decrease the cost of ePortfolio trials, as it eliminated the need for additional infrastructure expenses and simplified the technical integration with the institutional infrastructure. It also offered a cost effective business model suitable for smaller scale ePortfolio implementations.

The successful cooperation of higher education and the commercial sector led to fundamental technological redevelopment of PebblePad, the most common ePortfolio technology among Australian universities. Guided by the feedback of the PebblePad User Group, to better suit needs of academic users the new PebblePad3 was developed to integrate functionality of personal learning space, formal 
assessment space and an international network of participating institutions to provide a comprehensive ePortfolio system capable to support both, personal and institutional aspect of ePortfolio practice. The identified ePortfolio developments informed the update of the ePortfolio Matrix (Appendix A) to include only these ePortfolio technologies that met the expectations of Australian higher education market, and therefore were relevant for consideration by Griffith University. Consequently, the number of evaluated technologies dropped from 11 (in the 2008 ePortfolio Matrix) to 5, and their changed functionality was reflected in accordance with the adopted improvements.

The 2011 ePortfolio review established that implementation of a Google platform at Griffith University provided an immediate ePortfolio capability within the enterprise technological environment, that offered an opportunity for enhancing ePortfolio practice in learning and teaching across the university in support of the renewed academic curriculum. It gained a new momentum for ePortfolios at Griffith University, which led to a number of course level initiatives in 2012 and 2013, where Google Sites have been successfully used in ePortfolio practice to support student professional development in midwifery and education. In 2013, building on the expertise gained through ePortfolio research, Griffith implemented its first program level ePortfolio solution using Google Drive for clinical assessment of student midwives. Follow up research is intended to evaluate effectiveness of this initiative to inform any future program level ePortfolio implementations at Griffith as well as in other universities.

\section{Conclusion}

In 2008, when Griffith University joined the ePortfolio discussion, the technology's potential to enhance the academic learning and teaching environments was commonly recognised, but very few universities in Australia had first hand experience with ePortfolio tools, and the redevelopment of academic curriculum was generally still underway.

The immediate challenges that stood in the way of the ePortfolio's uptake in Australia included the lack of interoperability standards for the many ePortfolio technologies present on the market. This effectively hampered the capacity to migrate the learning content between the tools as students moved through the education system. Allowing students lifelong access to enterprise ePortfolio tools posed potential data storage implications with no cost effective solution available to universities. Portability of ePortfolio content or lifelong ePortfolio access was pivotal in ePortfolio tools' ability to properly support the agenda of student-centred evidence-driven lifelong learning increasingly adopted in Australian higher education.

The complexity of ePortfolio integration into the academic context was yet another challenge that required strong institutional commitment to provide strategic direction, engage players across the institution and secure appropriate funding (Hallam et al, 2010). From the institutional point of view, the user-centred ePortfolio technology also presented a significant risk, as the ePortfolio content would be controlled by users, but stored and shared under corporate branding, thus making the institution liable for any potential copyright issues and data security breaches, particularly in case of sensitive information. A good understanding of the potential impact of institutional ePortfolio uptake was essential to establishing comprehensive ePortfolio policies that could effectively regulate ePortfolios use.

The strategic work done by the Australian ePortfolio Project between 2007 and 2010, the successful cooperation of various ePortfolio communities of practice guiding advancements in ePortfolio functionality and increased accessibility of well documented ePortfolio case studies jointly contributed to the improved understanding of the ePortfolio practice and the increase in the number of ePortfolio trials in Australian higher education. As a result, many of the initial issues and challenges were gradually being addressed.

The key technological developments that increased the ePortfolios uptake among the Australian universities included initiatives such as Google for Education that made the issue of content portability and data storage obsolete as they provided lifelong access and high data allowance for students at no cost to the end user. Secondly, adoption of the Leap2A standard by the two most common ePortfolio technologies in Australian higher education, namely PebblePad and Mahara, enabled content portability between the compliant ePortfolio systems, thus further supporting student-centred approaches to learning. Thirdly, service of outsourcing data storage for institutional adopters of Mahara introduced a cost effective business model for ePortfolio technology adoption, which was reflected in the increasing 
number of Mahara trials and implementations. Lastly, the redevelopment of the PebblePad tool provided an ePortfolio technology well suited to higher education needs.

As the ePortfolio technologies and policies continue to mature, they provide a decisively more universityfriendly environment that can support a student-centred learning and teaching approach, as well as formal institutional processes. As ePortfolios continue to emerge as both compelling and effective mechanisms to measure student performance and monitor institutional quality, it is likely that ePortfolio practice will soon become a landmark of the renewed academic curriculum in Australia.

\section{Acknowledgments}

The authors are grateful for funding support from a Griffith University Learning and Teaching Committee grant and the contributions from the Griffith academic community.

\section{References}

AICTEC (Australian Information and Communication Technology in Education Committee) (2008a). Joint ministerial statement on information and communication technologies in Australian education and training: 2008-2011. Retrieved from

http://www.curriculum.edu.au/verve/_resources/AICTEC_JMS_on_ICT_in_Aust_Ed_and_Training.pdf

AICTEC (Australian Information and Communication Technology in Ëducation Committee) (2008b). Charter of principles for cross-sectoral collaboration on interoperability across the Australian education and training sectors. Retrieved from

http://www.curriculum.edu.au/verve/_resources/AICTEC_Standards_-_Charter_of_Principles.pdf

Gartner (2008). Hype Cycle of Higher Ēucation, 2008. Retrieved from http://www.gartner.com/DisplayDocument?id=70901

Hallam, G., Harper, W., McCowan, C., Hauville, K., McAllister, L., Creagh, T., ... Brooks, C. (2008). ePortfolio use by university students in Australia: Informing excellence in policy and practice. Australian ePortfolio Project - Final Report. AeP - Stage 1 Final Project Report (August 2008). Retrieved from http://www.eportfoliopractice.qut.edu.au/information/report/index.jsp

Hallam, G. \& Harper, W. \& Hauville, K. \& Creagh, T. \& McAllister, L. (2009). Australian ePortfolio Project- Stage 2. ePortfolio use by university students in Australia: Developing a sustainable community of practice. Final project report (December 2009). http://www.eportfoliopractice.qut.edu.au/information2/report_stage2/

Hallam, G. \& Harper, W. \& McAllister, L. \& Hauville, K. \& \&Creagh, T. (2010). Australian ePortfolio Project. ePortfolio use by university students in Australia: Informing excellence in policy and practice. Supplementary report: Oct. 2010. http://www.eportfoliopractice.qut.edu.au/survey/index.jsp

Jarrott, S, Eubanks Gambrel, L. (2011). The bottomless file box: Electronic portfolios for learning and evaluation purposes. International Journal of ePortfolio, 1(1), 85-94.

Lowenthal, P., White, J.W., \& Cooley, K. (2011). Remake/remodel: Using ePortfolio and a system of gates to improve student assessment and program evaluation. International Journal of ePortfolio, 1(1), 61-70.

Peet, M., Lonn, S., Gurin, P., Page Boyer, K., Matney, M., Marra, T., Himbeault Taylor, S., \& Daley, A. (2011). Fostering integrative knowledge through ePortfolios. International Journal of ePortfolio, 1(1), 11-31.

Ramirez, K. (2011). ePerformance: Crafting, rehearsing, and presenting the ePortfolio persona. International Journal of ePortfolio, 1(1), 1-9.

Shada, A., Kelly, K., Cox, R., \& Malik, S. (2011). Growing a new culture of assessment: Planting ePortfolios in the Metro Academies program. International Journal of ePortfolio, 1(1), 71-83.

Smart, C. (2010) . Enabling e-portfolio portability (Leap2A). Retrieved from http://www.jisc.ac.uk/publications/briefingpapers/2010/bpleap2a.aspx

Turns, J., Sattler, B., Eliot, M., Kilgore, D., \& Mobrand, K. (2012). Preparedness portfolios and portfolio studios. International Journal of ePortfolio, 2(1), 1-13. 
Corresponding author: Urszula Coffey, u.coffey@griffith.edu.au

Australasian Journal of Educational Technology (C) 2014.

Please cite as: Coffey, C., \& Ashford-Rowe, K. (2014). The changing landscape of ePortfolios: A case study in one Australian university. Australasian Journal of Educational Technology, 30(3), 284-294. 


\section{Appendix A}

The 2011 Griffith ePortfolio Matrix

\begin{tabular}{|c|c|c|c|c|c|}
\hline $\begin{array}{l}\text { ePortfolio tool } \\
\text { features }\end{array}$ & Expo Lx Sites & $\begin{array}{l}\text { ePortfolio in } \\
\text { Career Board }\end{array}$ & Google Sites & $\begin{array}{l}\text { PebblePad 3: } \\
\text { PebblePad + \& } \\
\text { ATLAS }\end{array}$ & Mahara 1.4 \\
\hline Griffith Supported & $\sqrt{ }$ & $\sqrt{ }$ & $\sqrt{ }$ & $\mathrm{X}$ & $\mathrm{X}$ \\
\hline $\begin{array}{l}\text { Hosted or self- } \\
\text { hosting }\end{array}$ & self-hosting & self-hosting & hosted & $\begin{array}{c}\text { hosted or self- } \\
\text { hosting over } 3000 \\
\text { users }\end{array}$ & $\begin{array}{l}\text { hosted or self- } \\
\text { hosting }\end{array}$ \\
\hline $\begin{array}{c}\text { Infrastructure } \\
\text { development cost }\end{array}$ & $x$ & $\begin{array}{l}\text { needs data } \\
\text { repository for } \\
\text { uploading files }\end{array}$ & $x$ & $\sqrt{ }$ if self-hosting & $\sqrt{ }$ if self-hosting \\
\hline $\begin{array}{l}\text { Annual service cost } \\
\text { per student }\end{array}$ & in $\mathrm{Bb}$ license & $\begin{array}{l}\text { in CareerBoard } \\
\text { license }\end{array}$ & in Google license & $\begin{array}{c}\text { HOSTED under } \\
1000 \text { users: } \\
\$ 2200+\$ 22 / \text { accnt } \\
\text { (below 500) or } \\
\$ 15 / \text { accnt }(500- \\
1000), \text { min } 50 \text { accnt }\end{array}$ & $\begin{array}{l}\text { HOSTED w/ Netspot: } \\
\$ 12800 \text { per } 1000 \\
\text { students, } 10 \mathrm{Mb} \\
\text { storage }\end{array}$ \\
\hline $\begin{array}{c}\text { Integration with the } \\
\text { uni LMS and SIS }\end{array}$ & $\sqrt{ }$ & $\sqrt{ }$ SIS & $\sqrt{\text { SIS }}$ & $\sqrt{ }$ & development rqrd \\
\hline $\begin{array}{c}\text { Support assessment } \\
\text { process integrated } \\
\text { with } \\
\text { Learning@Griffith } \\
\text { LMS }\end{array}$ & $\sqrt{ }$ work around & $x$ & $\sqrt{ }$ work around & $\checkmark$ when integrated & $x$ \\
\hline X. of ePortfolios & unlimited & unlimited & unlimited & unlimited & unlimited \\
\hline $\begin{array}{c}\text { Self-design options } \\
(\mathrm{Html})\end{array}$ & limited & $x$ & $x$ & $x$ & $x$ \\
\hline Templates & 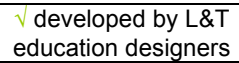 & $\begin{array}{l}\sqrt{ } \text { centrally pre-set by } \\
\text { tool administrator }\end{array}$ & $\sqrt{ }$ user created & $\begin{array}{l}\sqrt{\text { user created, very }} \\
\text { flexible }\end{array}$ & $x$ \\
\hline Flexible layout & $\sqrt{ }$ & $\mathrm{X}$ & $\sqrt{ }$ & $\sqrt{ }$ & $\sqrt{ }$ \\
\hline Text Editor (toolbar) & $\sqrt{ }$ & $\begin{array}{l}\mathrm{X} \text { format pre-set in } \\
\text { templates }\end{array}$ & $\sqrt{ }$ & $\sqrt{ }$ limited & $\sqrt{ }$ \\
\hline Embedding pictures & $\sqrt{ }$ and videos & $\mathrm{X}$ & $\sqrt{ }$ and videos & $\sqrt{ }$ & $\sqrt{ }$ and videos \\
\hline $\begin{array}{l}\text { Hyperlinking to } \\
\text { external sources }\end{array}$ & 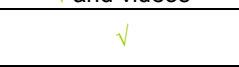 & $\sqrt{ }$ & ק & $\sqrt{ }$ & ק \\
\hline $\begin{array}{l}\text { Upload any type of } \\
\text { files }\end{array}$ & $\sqrt{ }$ & $\sqrt{ }$ & $\sqrt{ }$ & $\sqrt{ }$ & $\sqrt{ }$ \\
\hline $\begin{array}{c}\text { Cross-referencing of } \\
\text { the records }\end{array}$ & $x$ & $\sqrt{ }$ & $\sqrt{ }$ & $\sqrt{ }$ & ( \\
\hline Structured database & $\begin{array}{c}\text { X (data stored within } \\
\text { L@G) }\end{array}$ & $\begin{array}{c}\sqrt{\text { data storage }} \\
\text { development rqrd }\end{array}$ & $\sqrt{ }$ Google docs & $\sqrt{ }$ & $\begin{array}{c}\sqrt{\text { if hosted, data }} \\
\text { storage development } \\
\text { rqrd } \\
\end{array}$ \\
\hline $\begin{array}{l}\text { Summative view of } \\
\text { online records }\end{array}$ & $x$ & $\sqrt{ }$ & $\sqrt{ }$ & $\sqrt{ }$ & $\sqrt{ }$ \\
\hline $\begin{array}{c}\text { Storage space per } \\
\text { user }\end{array}$ & $1 \mathrm{~Gb}$ & policy decision & $10.5 \mathrm{~Gb}$ & $\begin{array}{c}250 \mathrm{Mb}+\text { (to be } \\
\text { confirmed) }\end{array}$ & $\begin{array}{c}10 \mathrm{Mb}(\$ 100 \text { for extra } \\
1 \mathrm{~Gb})\end{array}$ \\
\hline Authentication & Single sign on & Single sign on & Single sign on & $\begin{array}{l}\text { depends on level of } \\
\text { integration, Bb } \\
\text { building block would } \\
\text { support single sign } \\
\text { on }\end{array}$ & $\begin{array}{c}\text { can be integrated } \\
\text { with LMS }\end{array}$ \\
\hline $\begin{array}{c}\text { Range of sharing } \\
\text { permissions }\end{array}$ & $\sqrt{ }$ & $\sqrt{ }($ view \& comment $)$ & $\sqrt{ }$ & ( & $\sqrt{ }$ \\
\hline $\begin{array}{l}\text { General URL access } \\
\text { (for non-members) }\end{array}$ & $\sqrt{ }$ & $\begin{array}{l}\sqrt{\text { access per }} \\
\text { invitation only }\end{array}$ & $\sqrt{ }$ & ( & 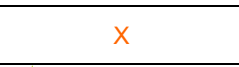 \\
\hline Portability (Export) & $\sqrt{\text { html and files }}$ & $\sqrt{ }$ word format & $\mathrm{X}$ & $\sqrt{\mathrm{html}}$ and Leap2A & $\sqrt{\mathrm{html}}$ and Leap2A \\
\hline $\begin{array}{l}\text { Interoperability } \\
\text { standards }\end{array}$ & $x$ & $\begin{array}{l}X \text { but offers lifelong } \\
\text { access for students }\end{array}$ & $\begin{array}{l}X \text { but offers lifelong } \\
\text { access for students }\end{array}$ & $\sqrt{ }$ supports Leap2A & $\sqrt{ }$ supports Leap2A \\
\hline Print & $\sqrt{ }$ & $\sqrt{ }$ & $\sqrt{ }$ & $\sqrt{ }$ & $\sqrt{ }$ \\
\hline Technical support & $\sqrt{ }$ L@G team & $\sqrt{ }$ Creative Eyes & $\sqrt{ }$ Google Help & $\begin{array}{l}\text { up to } 3 \text { designated } \\
\text { staff contacts }\end{array}$ & $\sqrt{ }$ Netspot \\
\hline Data security & standard compliant & standard compliant & standard compliant & standard compliant & standard compliant \\
\hline $\begin{array}{l}\text { Supporting } \\
\text { resources }\end{array}$ & $x$ & $\begin{array}{c}\text { internal development } \\
\text { required }\end{array}$ & ${ }_{1}$ & 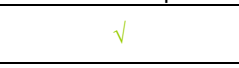 & ${ }^{2}$ \\
\hline $\begin{array}{c}\text { Rubrics/self- } \\
\text { evaluation tool }\end{array}$ & $x$ & $x$ & $x$ & $\begin{array}{c}\text { X under } \\
\text { development }\end{array}$ & $x$ \\
\hline $\begin{array}{l}\text { Integrated resume } \\
\text { builder }\end{array}$ & $x$ & $\sqrt{ }$ & $\mathrm{x}$ & $\sqrt{ }$ & $\sqrt{ }$ \\
\hline Integrated blog tool & $\sqrt{ }$ & $\mathrm{X}$ & $\sqrt{ }$ & $\sqrt{ }$ & $\sqrt{ }$ \\
\hline
\end{tabular}

